\title{
Trade and Growth In the Presence of Distortions
}

\author{
By \\ James Cassing* \\ and \\ Stephen Tokarick*
}

April 2005

\begin{abstract}
Tariffs and other policy distortions typically lower real national income relative to what it otherwise would have been for any given rate of factor accumulation. Even while lowering real income, however, policy distortions may raise an economy's real measured growth rate and so, somewhat deceivingly, give the impression that national welfare has benefited from things like tariff protection. This would be an incorrect conclusion. This paper discusses the issue of how policy distortions can affect the rate of growth for a small, open economy. For example, in the presence of exogenously given factor accumulation, a tariff can either raise or lower an economy's growth rate (measured by the change in the value of output at world prices), relative to the no-distortion growth rate. We also discuss the relevance of this result for tariff uniformity, "tariff jumping" foreign direct investment, and the empirical literature on trade and growth. Finally, we use a numerical simulation model of Egypt to assess whether the costs of its tax distortions have increased or declined over time.

Keywords: Tariffs, distortions, growth rate, factor accumulation

JEL classification Codes: F13, G41

*Cassing: University of Pittsburgh, Department of Economics, Pittsburgh, Pa. 15260. Phone: 412-648-8746. Email: jcassing@pitt.edu. Tokarick: International Monetary Fund, Research Department, $70019^{\text {th }}$ Street, N.W. Washington, D.C. 20431. Phone: 202-623-7590. Email: stokarick@imf.org. The views expressed are those of the authors and do not necessarily reflect the views of the IMF or IMF policy.
\end{abstract}




\section{Introduction}

Recently, economists and policy-makers have rekindled an interest in the links between trade policy and growth. In particular, there has emerged a large literature that revisits the empirical and theoretical linkages between the degree of an economy's openness to international trade and its real growth rate. While no real consensus has emerged in terms of theory or empirical regularities, the debate has largely focused on the linkages between measures of trade protection or other more domestic distortions and the rate of factor accumulation. Roughly, following early leads by Krueger (1978), the attention is on whether policy distortions, such as trade barriers, work to slow the rate of capital accumulation and thereby slow the real economic growth rate. (See especially Easterly $(1989,1993)$, Sachs and Warner (1995) and, for a nice summary, Baldwin (2003). Although theory is ambiguous regarding the relationship between greater openness to trade and economic growth (Brander and Krugman (1983), Rivera-Batiz and Romer (1991), Grossman and Helpman (1991), Parente and Prescott (2002)), most empirical work (Levine and Renelt (1992), Harrison (1996), Sala-iMartin (1997), Harrison and Hanson (1999), and Wacziarg and Welch (2003)) has generally found a positive relationship, although a fragile one, as pointed out by Rodriguez and Rodrik (2001). Clemens and Williamson $(2001,2002)$, for example, point out that the positive relationship between openness and growth was reversed in the period prior to 1950 for a number of countries.

However, less attention has been paid to the possibility that rather than slowing the rate of factor accumulation, the real cost of distortions might lie in the perverse incentives they create by directing any given level of factor growth to lower return (at world prices) industries. Thus, for example, while a policy-induced distortion such as an import tariff may discourage capital accumulation, it may also direct new investment to lower return activities (valued at world prices) and so lower the real measured growth rate in that way (Bhagwati (1968), Johnson $(1967,1970))$. Or, the same thing, the deadweight production cost of policy-induced distortions may be increasing in the presence of factor growth, independently of any effect they might have on the actual rate of factor accumulation, due to these intersectoral allocation considerations. But these effects are not explicitly captured in recent models of growth. (Berg and Krueger (2003) allude to this issue, but do not pursue it theoretically.)

At first face, such "mal-investment" in policy-protected sectors may seem an obvious source of reduced real growth. But this is not so obvious at all and, in fact, generally not correct. While policy-induced distortions such as import tariffs typically lower the level of real income, their effect on the real measured growth rate for any given rate of factor accumulation is ambiguous, depending on how various distortions influence the absorption of growing factor supplies across sectors. It would thus serve researchers and policy-makers well to be reminded that existing policy-induced distortions may raise or lower the real measured growth rate in an economy, even without affecting the rates of factor accumulation and certainly without raising welfare for small economies. One aim of this paper is to lay bare exactly what the ambiguity depends on and to present it in a way that is operationally useful to policy-makers. (The literature here is usefully reviewed in Corden (1997).) 
This perspective may be especially important for policy-makers who seek to increase a country's real income by encouraging growth through capital accumulation (savings and investment) and technological progress (technology transfer), but who cannot always dismantle existing barriers (e.g., tariffs), or must confront other fiscal realities requiring distortionary taxes (e.g., VATs), or political realities mandating distortionary subsidies (e.g., food). If the growth oriented policies are successful and the economy's underlying supply of capital and technology are augmented, some existing distortions will become less costly while others will become increasingly more onerous as their presence dictates that factor accumulation is not translated into real income growth at all. While a policymaker may well want to expend his political capital on dismantling the latter distortions but not the former, he first needs to know how to identify which is which.

This paper aims to sort out the issues involved and to focus the policymaker's attention on the parameters that influence how the costs of distortions are likely to change in the presence of growth. In section 2, we present a simple model of the relationship between a tariff distortion and the cost of the distortion (as a proportion of real national income) in a growing economy. In the absence of terms-of-trade effects, of course, a tariff will lower welfare when implemented initially and for every subsequent time period. But our focus is on the magnitude of the costs of distortions over time in the presence of factor accumulation. We also comment on growth and distortions more generally, and relate our results to the growth and openness literature. Section 3 presents some numerical examples of the effect of a change in a country's tariff on its growth rate and demonstrates how the growth rate might be affected for different values of key parameters. Section 4 illustrates the exercise for a stylized computable general equilibrium (CGE) model of Egypt. Finally, Section 5 offers some conclusions.

\section{The Effects of Distortions on Welfare in the Presence of Growth}

\section{A. The Effect of a Tariff on the Economy's Growth Rate}

Our focus is especially on how distortions affect real growth, not by any influence on the rate of factor accumulation, but rather through altering the intersectoral absorption of any particular level of factor growth. Thus, unlike the models of Easterly $(1989,1993)$, Parente and Prescott (2002), et al., we take the level of factor accumulation as exogenously determined along a growth path which may or may not be the long-run equilibrium path. That is, we do not constrain ourselves to "balanced growth" and, in fact, are particularly interested in factor accumulation or technical progress biased toward one sector or another. This seems to us the correct focus since we are interested in intermediate-run policy evaluation. Empirically, studies such as Young (1995) report decades of unbalanced growth for developing countries and this is indeed what we find for Egypt.

We begin with a standard neoclassical $2 \times 2$ variable proportions model based on the Cassing (1983) extension of Johnson (1970) of a small open economy producing goods X and Y using perfectly inelastically supplied factors capital $(\mathrm{K})$ and labor $(\mathrm{L})$. Using $\mathrm{a}_{\mathrm{ij}}, \mathrm{i}=\mathrm{L}, \mathrm{K}, \mathrm{j}=$ $\mathrm{X}, \mathrm{Y}$, to denote the input-output coefficients, the full employment conditions are given by: 
$a_{L X} X+a_{L Y} Y=L$

$a_{K X} X+a_{K Y} Y=K$

Solving (1) and (2) for output levels and substituting, we can write the expression for national income at world prices:

$$
M \equiv P_{X} X+P_{Y} Y=\frac{K\left(P_{X} a_{L Y}-P_{Y} a_{L X}\right)+L\left(P_{Y} a_{K X}-P_{X} a_{K Y}\right)}{a_{K X} a_{L Y}-a_{L X} a_{K Y}}
$$

where $P_{j}$ denotes the price of good j. Using “^” to denote proportional changes - e.g., $\mathrm{dM} / \mathrm{M}-$ the growth rate of national income at world prices is then given by:

$$
g \equiv \hat{M}=\frac{k \hat{K}\left(P_{X} a_{L Y}-P_{Y} a_{L X}\right)+\hat{L}\left(P_{Y} a_{K X}-P_{X} a_{K Y}\right)}{k\left(P_{X} a_{L Y}-P_{Y} a_{L X}\right)+\left(P_{Y} a_{K X}-P_{X} a_{K Y}\right)}
$$

where $k$ is the economy-wide capital-labor ratio. Note that the proportional change in real income - utility - coincides with the growth in output, given by equation (4), so long as prices are taken as fixed and preferences of the representative consumer are homothetic. That is, using the above notation and denoting consumption of each good by $\mathrm{X}_{\mathrm{C}}$ and $\mathrm{Y}_{\mathrm{C}}$, the budget constraint at world prices is given by $\mathrm{P}_{X} \mathrm{X}+\mathrm{P}_{\mathrm{Y}} \mathrm{Y}=\mathrm{P}_{\mathrm{X}} \mathrm{X}_{\mathrm{C}}+\mathrm{P}_{\mathrm{Y}} \mathrm{Y}_{\mathrm{C}}$. Now, since $\mathrm{X}_{\mathrm{C}}$ and $\mathrm{Y}_{\mathrm{C}}$ must change by the same proportion when income changes with prices constant due to homotheticity, if the lefthand side grows at a certain rate due to output changes, so must $X_{C}$ and $Y_{C}$ each grow at that rate. And, since preferences are homothetic, we can take the utility function to be linear homogeneous and so utility grows at the same rate.

Equation (4) reminds us of just how policy can influence an economy's real growth rate. Clearly, any policy-induced effect on factor accumulation will influence growth. This, of course, has been the focus of most of the growth literature, which offers a variety of models purporting to explain the connection between policy variables and capital accumulation. In the absence of any distortions, and noting that each $\mathrm{a}_{\mathrm{ij}}$ is fixed for any level of output prices, the real growth rate is a convex combination of the growth in the capital and labor supplies. Along a "balanced" growth path the rates of factor accumulation and the economy's growth rate will coincide. More generally, the growth rate will depend on the factor bias of the growth and on the relative factor intensities in production as output expands along a "generalized Rybczynski line."

However, while world output prices are assumed constant, each $\mathrm{a}_{\mathrm{ij}}$ depends on domestic factor prices and so on the policy environment. Factor prices, in turn, may be altered for a variety of reasons, including taxes and subsidies on either output or factors. (Imperfectly competitive output or input markets might also represent a distortion which could affect factor prices and so fall generally within the purview of the analysis here.) By altering each $\mathrm{a}_{\mathrm{ij}}$, any 
policy distortion will have an effect on how capital and labor accumulation translate into real growth. An extreme case, for example, is the possibility of "immiserizing tariffs" whereby an economy's import protection leads to negative real growth in the presence of factor accumulation (Bhagwati (1968), Johnson (1967)). While such effects are known to exist, the literature has not really explored the implications of domestic distortions for an economy's real growth rate simply owing to the altered intersectoral absorption of any given level of factor accumulation. Parente and Prescott (2002) do note that differences in domestic distortions across countries seem to explain differential growth rates better than do differences in savings rates.

For concreteness, and in light of recent interest in growth and openness, we focus on an import tariff. Consider the effect of an import tariff, $t$, levied ad valorem on the landed price of imported good X. Differentiating equation (4) with respect to $t$, but holding world prices constant and choosing units so that prices are initially unity, yields:

$$
\frac{d g}{d t}=\frac{k \hat{K}-\hat{L})\left(\frac{1}{\theta_{L X}-\theta_{L Y}}\right) t\left(\theta_{K X} \theta_{L X} \sigma_{X}-\frac{\theta_{K Y} \theta_{L Y}}{(1+t)} \sigma_{Y}\right)}{\left(\theta_{L Y}-\theta_{L X}\right)^{2}\left(\frac{\theta_{K}}{\theta_{L}}+1\right)^{2}}
$$

where $\sigma_{\mathrm{j}}$ and $\theta_{\mathrm{ij}}$ denote, respectively, the elasticity of substitution between labor and capital in industry $\mathrm{j}$, and factor i's cost share in industry $\mathrm{j}$. The terms $\theta_{\mathrm{K}}$ and $\theta_{\mathrm{L}}$ are the overall cost shares of capital and labor in the economy. In deriving equation (5), we have made use of the standard relationship between the input-output coefficients and factor price changes, noting that a tariff will alter domestic output prices and so factor prices. (See Cassing (1983) for the derivation of this expression.)

Equation (5) reveals that the real growth implication of a higher tariff depends on the bias of the economy's factor accumulation, relative factor intensities in the two sectors, the substitutability of capital for labor in each sector, and the initial tariff level. Note in particular that the effect of a higher tariff on the real growth rate is ambiguous in sign and potentially quite large. Below we discuss this result at some length and provide some numerical simulations. But first, we recall the correspondence between the real growth rate and the deadweight production cost of a distortion, as measured by the value of output at world prices with and without the distortion, since this may well be the most useful focus of policymakers.

\section{B. Cost of Protection in the Presence of Factor Accumulation}

Consider the deadweight production cost of a distortion, e.g., an import tariff, as measured by the equivalent variation in periods 0 and 1 , supposing that the economy's factor supply base (including "knowledge capital") grows between periods. Then, in period 0 , denoting the value of output at world prices without the distortion by $\mathrm{V}_{0}$ and with the distortion 
by $\mathrm{V}_{0}$, the deadweight production cost (as a fraction of undistorted income) is given by $\left(\mathrm{V}_{0^{-}}\right.$ $\left.\mathrm{V}_{0}{ }^{\prime}\right) / \mathrm{V}_{0}$. Now, in period 1 this will have changed to $\left(\mathrm{V}_{1}-\mathrm{V}_{1}{ }^{\prime}\right) / \mathrm{V}_{1}$. So, denoting the real growth rates with and without the distortion by $\mathrm{g}^{\prime}$ and $\mathrm{g}$, respectively, and noting that $\mathrm{V}_{1}=\mathrm{V}_{0}(1+\mathrm{g})$ and $\mathrm{V}_{1}{ }^{\prime}=\mathrm{V}_{0}{ }^{\prime}\left(1+\mathrm{g}^{\prime}\right)$, we can write the change in the proportional deadweight production cost (DPC) as:

$$
\Delta D P C=\left[\left(\frac{g-g^{\prime}}{1+g}\right)\right]\left(\frac{V_{0}^{\prime}}{V_{0}}\right)
$$

It follows that if the tariff-distorted growth rate exceeds the no-distortion growth rate, the proportional deadweight production cost would fall, and vice versa. That is,

$\Delta \mathrm{DPC} \underset{<}{\geq} \quad$ as $\quad \mathrm{g} \underset{<}{<}$

Thus, for any given rate of factor accumulation, if the economy's real growth rate is higher with the distortion than without $\left(\mathrm{g}^{\prime}>\mathrm{g}\right.$ ), then the deadweight production cost of the tariff (as a share of national income at world prices) is decreasing. In the case of the import tariff discussed above, equation (5) governs the change in the deadweight production cost owing to a higher tariff. If the sign of $\mathrm{dg} / \mathrm{dt}$ is positive, then the deadweight production cost of a tariff would fall as the economy grows.

As a practical matter, this relationship between growth rates and deadweight costs is extremely important to a policy-maker. Typically, policy aims to enhance capital accumulation (or technology transfer), but the factor accumulation takes place in the context of a distorted economy. Nonetheless, some distortions may be getting less costly with growth, while others might become more costly. Our analysis of growth and distortions will thus serve to alert the policy-maker as to which observable parameters are likely to matter and this, in turn, should assist in any decision as to which distortions deserve the most political attention and which may not be worth expending political effort on.

\section{Parameter Values and the Magnitude of $\frac{d g}{d t}$}

We divide our analysis into qualitative and quantitative effects. While we focus on a tariff, any price distortion can have similar effects. In fact, as a policy matter, non-tariff distortions may well be of the most consequence. Nonetheless, tariffs seem to get more attention in the literature and so are the focus of our analysis until Section 4 where we introduce other taxes as well in our CGE exercise.

\section{The sign of $d g / d t$}

In this section, we return to a discussion of the tariff distortion in particular. Equation (5) reveals that a higher tariff may increase or reduce an economy's real growth rate for a given 
injection of capital and labor. The sign of dg/dt depends on the particular configuration of parameters, with the possibilities recounted in Table 1. For example, the first line of the table indicates that for the capital intensities and substitution parameters shown, if the rate of capital accumulation exceeds growth in the labor endowment, a higher tariff in place will result in a higher real growth rate. The second line of Table 1 shows that if labor supply growth exceeds capital supply growth, this result is reversed. There are eight permutations of parameters, and

Table 1. Sign of $d g / d t$

$$
(\hat{K}-\hat{L}) \quad\left(\theta_{L X}-\theta_{L Y}\right) \quad\left(\theta_{K X} \theta_{L X} \sigma_{X}-\frac{\theta_{K Y}}{(1+t)} \theta_{L Y} \sigma_{Y}\right) \quad \mathrm{d} g / \mathrm{d} t
$$

\begin{tabular}{ccccc}
\hline & + & + & + \\
- & + & + & - \\
+ & - & + & - \\
- & - & + & + \\
+ & + & - & + \\
- & + & - & + \\
+ & - & - & - \\
\hline
\end{tabular}

four are consistent with higher tariffs leading to higher measured real income growth. (The magnitude of the effect on real growth depends on the actual parameter values which are in principle observable to the policymaker and investigated below, and in Sections III and IV.)

The intuition of the affect of factor growth on real income growth turns on factor substitution possibilities in the various sectors. For example, suppose that the capital stock is growing faster than the labor force and that the tariff protected import sector is relatively labor intensive. Then, using Table 1's summary of the sign of equation (5), the effect of such capital accumulation on real growth when the tariff is higher takes on the sign of $\left(\theta_{\mathrm{KX}} \theta_{\mathrm{LX}} \sigma_{\mathrm{X}}-\right.$ $\left.\theta_{\mathrm{KY}} \theta_{\mathrm{LY}} \sigma_{\mathrm{Y}} /(1+\mathrm{t})\right)$. If the substitution elasticities were both zero, then a higher tariff would have 
no effect on the economy's growth rate, since factor intensities in production would be unaffected and the infusion of capital and labor would be absorbed in the same way, leading to the same real growth rate. But, if $\theta_{K X} \theta_{L X} \sigma_{X}>\theta_{K Y} \theta_{L Y} \sigma_{Y} /(1+t)$, then the higher tariff induced wage-rental ratio causes the labor-intensive $X$ industry to increase its capital-labor ratio by more than the capital-intensive $\mathrm{Y}$ industry. This means that the infusion of a relatively capital abundant bundle of resources will need to be absorbed in the economy by the X industry contracting more (or, at least, expanding less) than it would have in the absence of the tariff. But, since the tariff distorted industry was already producing too much, real income actually grows by more than with a lower distortion. Figure 1 illustrates the cases of Table 1 wherein the higher tariff reduces the real growth rate. We assume that a no-tariff regime is compared with a discretely positive tariff regime and that capital and labor accumulation are exogenously given. ("Discretely positive" because we recognize that a small tariff for a small country carries no deadweight production cost).

Figure 1: Tariff Distortion Lowers the Growth Rate

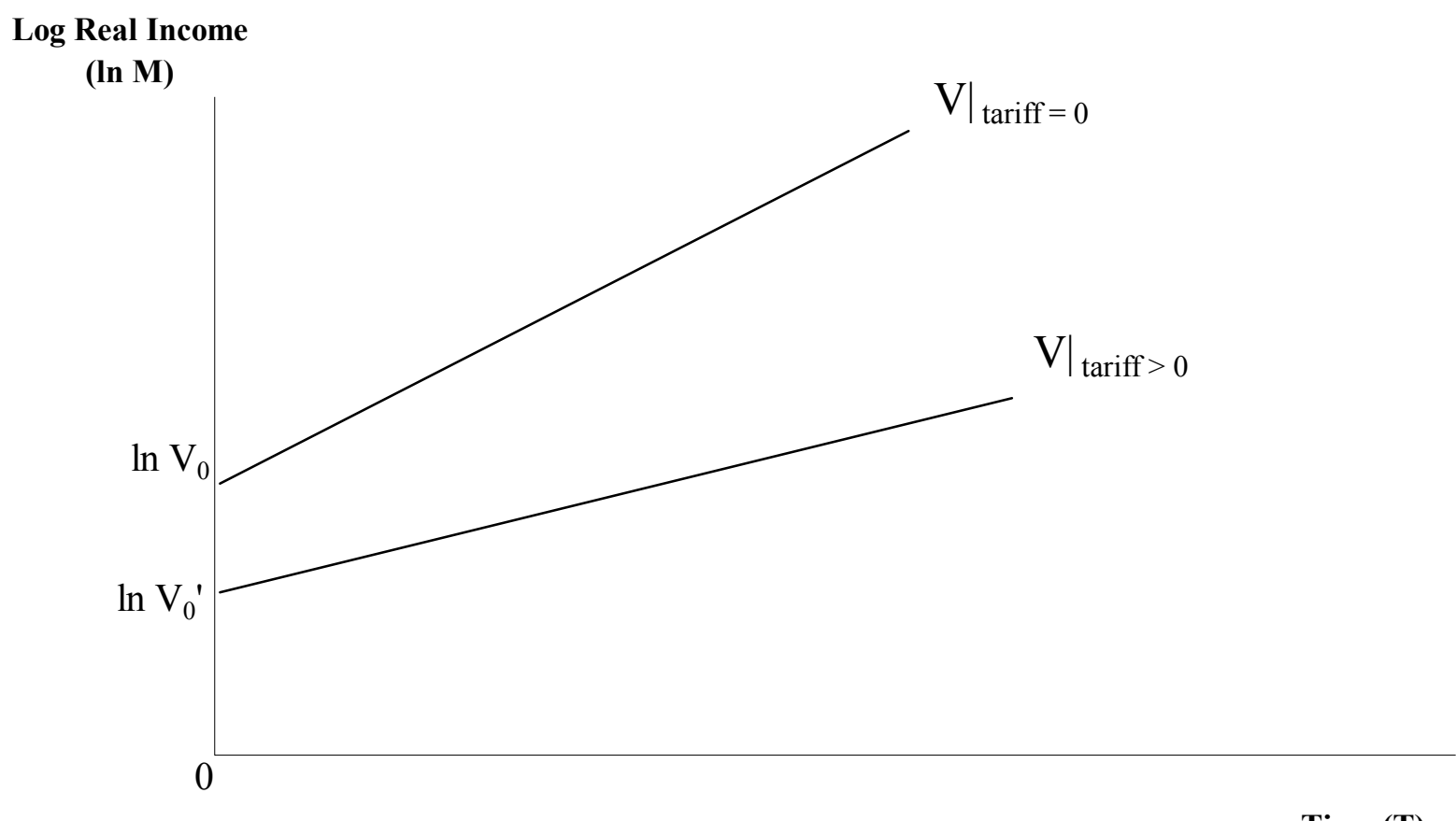

Time (T)

We measure real income in the natural logarithm so that the slope of the path is the growth rate. In period 0 , when the tariff is applied, real income is lowered by the deadweight production cost of the tariff- from $\mathrm{V}_{0}$ to $\mathrm{V}_{0}{ }^{\prime}$. As factor supplies grow, the undistorted economy will grow at a constant rate along a generalized Rybczynski line. (If the endowment grows in a manner that leads to specialization in one of the goods, then diminishing marginal productivity for the faster growing factor will set in and the growth path will be concave, but still increasing, beyond that point.) The distorted growth path is shown to not only lie below the undistorted path, but to exhibit a lower real growth rate. Hence, the deadweight production cost of the tariff is ever 
increasing. The case of an "immiserizing tariff" would correspond to a negatively sloped distorted growth path.

Figure 2 illustrates the cases in Table 1 for which the distorted real growth is higher, at least at first. Again, at time 0 the distorted real income begins below the undistorted real income owing to the deadweight cost of the tariff. But, as illustrated, the distorted growth rate exceeds the undistorted one so that the two paths begin to converge. In this case, the deadweight cost of the tariff is falling as the factor growth interacts with technology in a favorable way. In a sense, the economy is "growing out" of the cost of the initial distortion. Of course, at some point -

Figure 2: Tariff Distortion Raises the Growth Rate

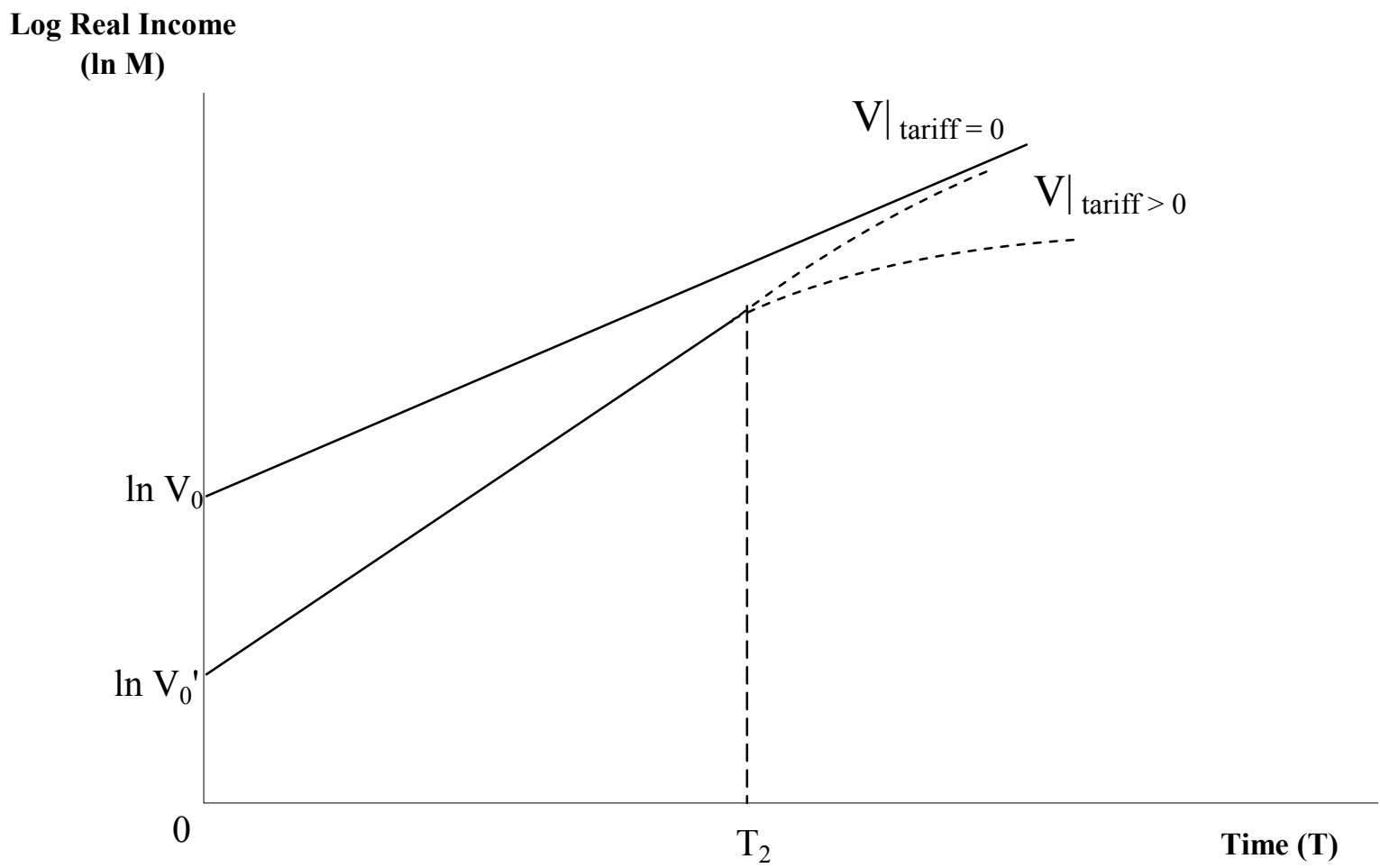

time $\mathrm{T}_{2}$ in Figure 2 - the distorted growth rate must fall since real income with the distortion can never exceed real income without. We show two alternative growth paths. As shown, the distorted path can approach asymptotically the undistorted path. This means that the distortion could forever raise the real growth rate for an economy, but, of course, never raise real income. This point serves to caution researchers about any preoccupation with growth rates when it is real income levels that are of interest (Berg and Krueger (2003) make a similar cautionary comment). There are, in fact, obvious examples where a distortion carries no deadweight cost at all over time, as when an economy is specialized in the production of a good whether it is protected or not. Again, to reiterate the important distinction between levels and growth, it is the discounted present value of income - the properly discounted value of the area between the 
growth path curves - that matters for welfare, not the comparative growth rates. Next we turn to a discussion of the magnitudes of the differential levels of contemporaneous real income with and without a higher tariff. In terms of the figures, this represents the difference between the growth path curves.

\section{The Magnitude of the Differential Growth Rates}

The magnitude of the differential growth rates induced by distortions depends on the actual parameter and technology values. Below, in Section III, we will offer some numerical simulations indicative of what is possible. Here, however, we begin a discussion based on equation (5) and identify the role of some of the critical policy and technical parameters.

In assessing the effect of a distortion on an economy's growth rate, note that initial policy conditions matter. In particular, the initial level of the tariff distortion appears explicitly and positively in equation (5). This suggests that the impact on the real growth rate of increasing a tariff is greater starting from an initially higher tariff. Thus, if a country already has substantial tariff protection, and if factor shares and substitution elasticities are assumed to be constant, then raising the tariff further is likely to raise or lower the real growth rate by more, compared with an initially lower tariff regime. Certainly, if the initial tariff level were zero, increasing the tariff rate infinitesimally would not affect the real growth rate, but if the initial tariff were already positive, then there would be an effect. Analytically, the magnitude of the effect revolves around the sign of $\mathrm{d}^{2} \mathrm{~g} / \mathrm{dt}^{2}$, which is complex and not obvious in sign when calculated since factor shares and substitution elasticities in general depend on the tariff rate. However, our simulation examples, reported in the next section, illustrate that the growth effects of increased tariffs in fact increase in magnitude with the initial level of protection. So, for example, under the conditions that incrementally higher tariffs lower the growth rate, starting from higher initial tariff levels will cause incrementally higher tariffs to lower the growth rate by even more.

We focus next on the substitution elasticity and labor intensity in the protected $\mathrm{X}$ sector, holding the other sector's values constant. (We note, of course, that what matters are the relative differences between the $\mathrm{X}$ and $\mathrm{Y}$ sectors.) Consider first the role of relative substitution elasticities. Differentiating equation (5) with respect to $\sigma_{X}$ yields:

$\operatorname{sgn} \frac{d^{2} g}{d t d \sigma_{x}}=\operatorname{sgn}(\hat{K}-\hat{L})\left[\frac{1}{\left(\theta_{L X}-\theta_{L Y}\right)}\right]$

Suppose that the importable is relatively labor intensive and that capital is growing faster than labor. Then, the expression in (7) is positive. Therefore, a higher elasticity of substitution in the import-competing X sector increases the effect of raising tariffs on real growth. Intuitively, suppose that initially the technology is Leontief so that the substitution elasticities are zero in both industries. Since a tariff cannot change the factor intensities in the industries, which govern how industry output will change with factor growth, a tariff change has no effect at all on the value of output at world prices (This is consistent with equation (5)). However, if we 
now allow some factor substitution in the $\mathrm{X}$ industry, i.e., $\sigma_{\mathrm{X}}>0$, then the tariff will have a non-zero effect on the growth rate, since the factor intensity of the $\mathrm{X}$ sector will be altered.

The relative magnitudes of factor intensities across sectors also clearly matters for the effect of a tariff change on growth. However, differentiating equation (5) with respect to $\theta_{\mathrm{LX}}$ and noting that $\theta_{\mathrm{LX}}+\theta_{\mathrm{KX}}=1$, yields an expression for $\frac{d^{2} g}{d t d \theta_{L X}}$ which is ambiguous in sign and depends on particular numerical values of the parameters. The complication arises because, as can be seen from equation (5), the effect of a change in a tariff on growth depends on not just the relative factor intensities and the bias of the factor accumulation, but also on how sectors are "weighted" by substitution elasticities and by the relative magnitudes of factor intensities initially. Among other things, for example, the sign of $\frac{d^{2} g}{d t d \theta_{L X}}$ depends on whether the value of $\theta_{\mathrm{LX}}$ is greater or less than 0.5 . This condition is reminiscent of a factor's "importance", as discussed in Jones and Scheinkman (1977). Since the sign conditions are fairly complex, we simply note here the potential ambiguity.

Finally, note from equation (5) that the overall economy-wide share of capital (or labor) also plays a role in determining the magnitude of the effect of a tariff change on the real growth rate. But since the relative overall factor-share terms $-\theta_{\mathrm{K}} / \theta_{\mathrm{L}}$ and $k$-enter positively in the denominator and ambiguously in the numerator, depending on parameter values, an increase in this ratio may serve to increase or reduce the effect of a change in the tariff rate on real growth. That is, a country being relatively more capital abundant could have a positive effect for higher tariffs on growth, while a less capital abundant country would have the opposite effect, assuming as usual that all other values are the same between countries. Specifically, the numerator is governed by the combinations reported in Table 1 above.

\section{E. Comments on Some Applications and Related Propositions in the Trade Literature}

The effect of factor accumulation on the costs of existing distortions in an economy can clearly be related to some interesting policy issues for open economies. Two such issues are the case for a uniform tariff, and the welfare effects of tariff induced foreign direct investment, or "tariff jumping."

In our theoretical model, we have only one import-competing sector, so any tariff regime is necessarily uniform. However, our methodology could be extended to include any number of sectors. In our simulation results with the two-sector model in Section III below, we find that when a higher tariff raises the economy's growth rate $(\mathrm{dg} / \mathrm{dt}>0)$, growth rises at an increasing rate $\left(\mathrm{d}^{2} \mathrm{~g} / \mathrm{dt}^{2}>0\right)$. And when a higher tariff lowers the economy's growth rate $(\mathrm{dg} / \mathrm{dt}$ $<0)$, growth declines at an increasing rate $\left(\mathrm{d}^{2} \mathrm{~g} / \mathrm{dt}^{2}<0\right)$. So, with parameter values for which a higher tariff lowers the real growth rate, raising a tariff will reduce real growth, and the magnitude of this reduction will be less than the increase in the real growth rate that would result from reducing a higher tariff. Now, if this proposition extends to a multi-sector model, 
and since real growth is a weighted sum of sector growth rates, then moving to a low, uniform import tariff by raising lower tariffs and reducing higher ones should raise the overall real growth rate. That is, a uniform tariff would be associated with a smaller deadweight production loss imposed by any given level of factor accumulation. In contrast, in the case where a higher tariff raises the economy's real growth rate, raising the lowest tariff and reducing the highest tariff would lower the economy's growth rate. These conclusions, however, need to be modified somewhat to take account of possible interaction effects arising from changes in one tariff rate in the presence of another. The conclusions that follow from equation (5) are based on the assumption that there is only one tariff distortion in place.

As a second application, consider the Brecher-Diaz-Alajandro (1977) proposition that foreign capital enticed into tariff protected sectors lowers welfare as the capital's owners repatriate artificially high rates of return. While we do not have a theory of endogenous capital accumulation, suppose that a given tariff level is associated with some flow of "tariff jumping" foreign capital inflow. Then, the productivity of this capital at world prices will contribute to the economy's real growth rate. The Brecher-Diaz-Alajandro result turns on the capital being rewarded in excess of the value of what it is producing measured at world prices. If this excess is changing over time due to factor accumulation, then this is part of the welfare cost. Our analysis presents the conditions under which this cost, while always there, will get larger or smaller over time. In particular, for a stylized portrayal of a developing country offered as Example 4 in our simulations in Section III, that cost gets larger over time. The host country is not only worse off for the distortion induced capital inflow, but furthermore that cost is rising. Prudent policy might dictate reducing the tariff.

Next, we offer a comment on implications for the econometrics of the openness and growth debate. But we add the cautionary note here that our analysis once again reminds us that some policies, like tariffs, can cause higher measured real growth rates while at the same time lowering real income.

\section{F. Implications for Empirical Work on International Openness and Growth}

Finally, before turning to some specific numerical examples, we offer a comment on the implications of our analysis for the econometrics of the openness and growth debate. Fairly standard growth regressions, such as those suggested by Levine and Renelt (1992), regress per capita GDP growth on the initial level of GDP, the investment ratio, the initial level of secondary school attainment rates, and the population growth. Cross-country data are employed and so growth and investment are measured as period averages. To this are appended some measures of "openness" or, commonly, just average ad valorem tariffs as measured by import duties as a percentage of imports. Thus, for example, an estimating equation might be given as in Baldwin and Sbergami (2000) by:

$$
g_{i}=\beta_{0}+\beta_{1} i n v_{i}+\beta_{2} \text { pop }_{i}+\beta_{3} G D P_{0 i}+\beta_{4} \text { human }_{0 i}+\beta_{5} \text { trade }_{i}+\varepsilon_{i}
$$


Priors on the signs are typically given as $\beta_{1}$ and $\beta_{4}$ positive (relating to physical investment and human capital accumulation), $\beta_{2}$ and $\beta_{3}$ negative (relating to population growth and the initial level of GDP aimed to capture any "catch-up effect"). Of course, $\beta_{5}$ is the object of some scrutiny, although a negative sign for tariff levels as the trade variable is often implicitly expected in the literature. In fact, this version of the model does not perform all that well when confronted with the data. Edwards (1998), for example, depending on which particular variable constructs are used, finds insignificant coefficients most of the time. The sign on the trade variable changes and is insignificant in seven of ten specifications. (The investment ratio is the exception, being significantly positive always.)

Baldwin, guided by relatively recent theory such as Brander and Krugman (1983), posits a non-linear specification for the trade variable, which improves the significance of other variables as well as the explanatory power of the model. His point is that we should expect the impact of tariffs on growth to vary with the height of the tariff.

Our reasoning would similarly be critical of the original econometric specifications since not only is the sign and magnitude of a tariff's effect on growth ambiguous, but so are the effects of factor accumulation depending on the factor intensities and substitution elasticities in industries, and on the initial height of the tariff. If derived from the $2 \times 2$ model with a tariff distortion, any cross-country regression of growth rates on tariff levels might well be expected to be fragile. This may also explain why grouping the sample of countries along lines of "higher" and "lower" income (DeJong and Ripoll (2004)), or elsewise, seems to matter. Equation (5), for example, suggests that the factor intensity of the export sector will alter the relationship between the height of the tariff and the growth rate. In a $2 \times 2$ model, other things equal, whether a country exports the labor-intensive good or the capital-intensive good would actually change the expected sign of the coefficient on tariffs in a typical growth regression model. Thus, putting countries that export goods of the same factor intensity into a separate sample should improve the explanatory power of a regression model. Grouping by per capita income or some other measure of development might capture this.

\section{Some Numerical Examples}

In this section, we present some numerical simulations to illustrate how changes in a tariff affect an economy's growth rate for different sets of parameter values. The applied general equilibrium model used in this section is similar in structure to the traditional two-good, two-factor model of production that is used extensively in trade theory and explained in Jones (1965). The model includes two goods (exportables and importables), produced using two inputs (labor and capital), which are freely mobile across sectors, under constant returns to scale. National income is the sum of the income earned by all factors of production plus tariff revenue. A representative consumer is assumed to maximize a Cobb-Douglas utility function, subject to a budget constraint, which gives rise to demand functions for each of the two goods. The terms of trade are given, and the world price of the importable good is taken to be the numeraire. Equilibrium is characterized by a set of factor prices and output levels such that factors of production are fully employed and price equals average cost in each sector. Of 
course, at the equilibrium set of factor prices and output levels, trade is balanced (at world prices).

We implement the model, using a constant elasticity of substitution (CES) production function for each good, for a variety of parameter values as discussed below. We report the results of four simulations which illustrate a range of outcomes for the effect of a higher tariff on growth and are based on reasonable parameter values.

\section{Results of the Simulations}

We begin with an example, the results of which are presented in Table 2, of how a tariff distortion may actually raise the real measured growth rate for an economy. Again, we emphasize that a tariff for a small open economy cannot raise real income, but the reduction in real income owing to the tariff distortion can become smaller over time with factor accumulation. But, as the numbers will make clear, a higher growth rate induced by a tariff distortion is certainly not welfare improving. On the contrary, the welfare loss can be quite substantial and the preferred policy would be no tariff at all.

Table 2 shows the effect on the real growth rate of a 5 percent rate of capital accumulation while the endowment of labor remains unchanged. The import-competing $X$ sector is taken to be relatively labor intensive, with labor's share initially at 0.8 versus 0.25 in the exporting Y sector. Finally, the elasticity of factor substitution in the X sector exceeds that in the $Y$ sector, 1.5 versus 0.2 . In the absence of a tariff distortion $-t=0-$ the increase in the endowment of capital leads to growth in national output of 2.83 percent, valued at undistorted, world prices. In table 2, this is shown in the first row by the change in real income from $\$ 3000$ to $\$ 3085$. (Monetary units may be thought of as in millions or billions of U.S. dollars if that offers a sense of proportion.) For higher levels of the tariff, the same factor growth results in higher real growth rates. For example, the second line of Table 2 reports that a ten percent tariff $-\mathrm{t}=0.1-$ lowers real national income initially by the production cost $\$ 5.83$, or about 0.194 percent of national income. But the real growth rate rises to 2.84 percent. Correspondingly, the production cost of the distortion has fallen with factor growth to $\$ 5.78$. 
Table 2. The Tariff-Distorted Growth Rate Exceeds the No-Distortion Growth Rate

Initial values: $\theta_{\mathrm{LX}}=0.8, \theta_{\mathrm{LY}}=0.25$, tariff $=0, \sigma_{\mathrm{x}}=1.5, \sigma_{\mathrm{y}}=0.2$

With Factor Accumulation $(\hat{K}=5, \hat{L}=0) \quad$ Without Factor Accumulation

\begin{tabular}{ccccccccc}
$\begin{array}{c}\text { Tariff } \\
\text { Rate }\end{array}$ & $\begin{array}{c}\text { Growth } \\
\text { Rate }\end{array}$ & $\begin{array}{c}\text { Value of } \\
\text { Production } \\
\text { (At world } \\
\text { prices) }\end{array}$ & $\begin{array}{c}\text { Production } \\
\text { Cost (In } \\
\text { dollars) }\end{array}$ & $\begin{array}{c}\text { Production } \\
\text { Cost as a } \\
\text { of National } \\
\text { Income }\end{array}$ & $\begin{array}{c}\text { Value of } \\
\text { Production } \\
\text { (At world } \\
\text { prices) }\end{array}$ & $\begin{array}{c}\text { Production } \\
\text { Cost (In } \\
\text { Dollars) }\end{array}$ & $\begin{array}{c}\text { Production } \\
\text { Cost as a \% } \\
\text { of National } \\
\text { Income }\end{array}$ \\
\hline & & & & & & & & \\
0.0 & 2.8333 & 3085.00 & 0.0 & 0.0 & 3000.00 & 0.0 & 0.0 \\
0.1 & 2.8419 & 3079.262 & 5.78 & 0.186 & 2994.171 & 5.83 & 0.194 \\
0.2 & 2.8737 & 3058.713 & 26.287 & 0.852 & 2973.271 & 26.729 & 0.890 \\
0.3 & 2.9443 & 3015.095 & 69.905 & 2.266 & 2928.861 & 71.139 & 2.371 \\
0.4 & 3.0890 & 2931.352 & 153.648 & 4.980 & 2843.515 & 156.485 & 5.216 \\
0.5 & 3.4077 & 2765.727 & 319.273 & 10.349 & 2674.584 & 325.415 & 10.847
\end{tabular}

Source: Model simulations

As the level of the tariff is increased further, the effects of the same rates of factor accumulation on the growth rate are amplified. In the absence of growth, a 50 percent tariff imposes a production cost on the economy of $\$ 325.42$, or 10.85 percent of national income at world prices. But the 5 percent growth in the capital supply now results in a 3.41 percent real growth rate - almost 60 basis points higher than without the distortion. That is almost a 22 percent increase in the real measured rate of growth owing only to the tariff distortion. In growth accounting terms, that seems quite high and would certainly be noticeable in any econometric growth regression.

As the tariff increases in this example, the real growth rate increases at an increasing rate. Or, comparing the difference in the two columns of production costs with and without growth, the deadweight production cost difference falls at an increasing rate as the tariff barrier gets higher. This occurs because the higher tariff regime is associated with a more than proportionately higher production cost before factor accumulation, reflecting the usual welfare calculus property that the (production) cost of a tariff distortion rises with the square of the proportional increase in the tariff. But the production cost of any given tariff level in the presence of growth, while rising with factor accumulation, does so at a slower rate in this example. Hence, the difference in the production cost with and without factor accumulation increases at an increasing rate as the tariff level is set higher. 
Table 3 is similar to Table 2 except that the labor supply is growing at 5 percent with the capital stock fixed. The relative factor intensities (shares) and substitution elasticities are as in Table 2. In this case, as would be expected from the earlier theoretical discussion and noting that only the bias of the factor accumulation has changed from the previous example, a higher tariff distortion reduces the economy's real growth rate. In fact, compared with no distortion, a tariff of fifty percent reduces the real growth rate by 57 basis points, from 2.167 percent to a mere 1.592 percent (Table 3 ). In the context of trade and development, this is a fairly serious additional indictment of tariff protection. Without any factor accumulation, the tariff reduced real income by over ten percent of the value of production at world prices. But this initial welfare cost is further compounded in the presence of labor supply growth as the distortion becomes even more costly over time, with the production cost of the tariff now rising to over eleven percent of the undistorted value of output.

Table 3. The Tariff-Distorted Growth Rate is Less Than the No-Distortion Growth Rate

Initial values: $\theta_{\mathrm{LX}}=0.8, \theta_{\mathrm{LY}}=0.25$, tariff $=0, \sigma_{\mathrm{x}}=1.5, \sigma_{\mathrm{y}}=0.2$

With Factor Accumulation $(\hat{K}=0, \hat{L}=5) \quad$ Without Factor Accumulation

\begin{tabular}{|c|c|c|c|c|c|c|c|}
\hline $\begin{array}{l}\text { Tariff } \\
\text { Rate }\end{array}$ & $\begin{array}{c}\text { Growth } \\
\text { Rate }\end{array}$ & $\begin{array}{l}\text { Value of } \\
\text { Production } \\
\text { (At world } \\
\text { prices) }\end{array}$ & $\begin{array}{c}\text { Production } \\
\text { Cost (In } \\
\text { dollars) }\end{array}$ & $\begin{array}{c}\text { Production } \\
\text { Cost as a } \\
\% \text { of } \\
\text { National } \\
\text { Income } \\
\end{array}$ & $\begin{array}{l}\text { Value of } \\
\text { Production } \\
\text { (At world } \\
\text { prices) }\end{array}$ & $\begin{array}{c}\text { Production } \\
\text { Cost (In } \\
\text { Dollars) } \\
\end{array}$ & $\begin{array}{c}\text { Production } \\
\text { Cost as a } \\
\% \text { of } \\
\text { National } \\
\text { Income } \\
\end{array}$ \\
\hline 0.0 & 2.1667 & 3065.00 & 0.0 & 0.0 & 3000.00 & 0.0 & 0.0 \\
\hline 0.1 & 2.1581 & 3058.788 & 6.212 & 0.203 & 2994.171 & 5.829 & 0.194 \\
\hline 0.2 & 2.1263 & 3036.492 & 28.508 & 0.930 & 2973.271 & 26.729 & 0.891 \\
\hline 0.3 & 2.0557 & 2989.065 & 75.935 & 2.477 & 2928.861 & 71.139 & 2.371 \\
\hline 0.4 & 1.9110 & 2897.854 & 167.146 & 5.453 & 2843.515 & 156.485 & 5.216 \\
\hline 0.5 & 1.5923 & 2717.171 & 347.829 & 11.348 & 2674.584 & 325.415 & 10.847 \\
\hline
\end{tabular}

Source: Model simulations.

In this case where the cost of the distortion in place rises with factor accumulation, the cost also rises at an increasing rate as the tariff is raised. That is, in terms of real growth, the real growth rate falls at an increasing rate as the tariff level rises. Indeed, referring to the first two columns of table 3 , raising the tariff from zero to 10 percent reduces real growth by about 0.01 of 1 percent. But raising the tariff from 40 percent to 50 percent results in a diminution of the real growth rate by over 0.3 of 1 percent. In terms of real income growth, the undistorted economy would double its real income in 33 years. In contrast, this same economy, with the exact same labor supply growth but with a 50 percent import tariff, would start from a lower 
level of real income due to the distortion and take over 45 years to double this smaller initial real income. It is tempting to assume that the real growth rate falls in Table 3 compared to Table 2, merely because, in Table 3, factor growth is extremely biased toward the distorted labor-intensive, import-competing sector, while in Table 2, factor accumulation is extremely biased toward the capital-intensive undistorted export sector. But this is not the whole story, as Table 4 makes clear.

In Table 4, as in Table 3, labor supply is growing at 5 percent with the capital stock fixed and the factor intensities remain unchanged, with the import-competing $\mathrm{X}$ industry being relatively labor intensive and factor shares unchanged. But now, we reverse the substitution elasticities in production, using $\sigma_{X}=0.2$ and $\sigma_{Y}=1.5$. As shown in the first two columns of Table 4, higher tariff rates are now associated with higher real growth rates, despite the extreme bias of the factor accumulation toward the labor intensive tariff-distorted X sector, in contrast to Table 3. Of course, equation (5) had already alerted us to this possibility. But it serves the policy-maker to be reminded not to focus only on the bias of factor accumulation when trying to assess which distortions may become more or less costly with growth.

Table 4. The Tariff-Distorted Growth Rate is Greater Than the No-Distortion Growth Rate

\begin{tabular}{|c|c|c|c|c|c|c|c|}
\hline \multirow[b]{2}{*}{$\begin{array}{l}\text { Tariff } \\
\text { Rate }\end{array}$} & \multicolumn{4}{|c|}{ With Factor Accumulation ( $K=0, L=5)$} & \multicolumn{3}{|c|}{ Without Factor Accumulation } \\
\hline & $\begin{array}{c}\text { Growth } \\
\text { Rate }\end{array}$ & $\begin{array}{l}\text { Value of } \\
\text { Production } \\
\text { (At world } \\
\text { prices) }\end{array}$ & $\begin{array}{c}\text { Production } \\
\text { Cost } \\
\text { (In dollars) }\end{array}$ & $\begin{array}{c}\text { Production } \\
\text { Cost as a \% } \\
\text { of National } \\
\text { Income }\end{array}$ & $\begin{array}{l}\text { Value of } \\
\text { Production } \\
\text { (At world } \\
\text { prices) }\end{array}$ & $\begin{array}{l}\text { Production } \\
\text { Cost } \\
\text { (In dollars) }\end{array}$ & $\begin{array}{c}\text { Production } \\
\text { Cost as a \% } \\
\text { of National } \\
\text { Income }\end{array}$ \\
\hline 0.0 & 2.16667 & 3065.00 & 0.0 & 0.0 & 3000.00 & 0.0 & 0.0 \\
\hline 0.1 & 2.17353 & 3057.676 & 7.324 & 0.238956 & 2992.631 & 7.369 & 0.245633 \\
\hline 0.2 & 2.18812 & 3042.081 & 22.919 & 0.747765 & 2976.942 & 23.058 & 0.7686 \\
\hline 0.3 & 2.20562 & 3023.389 & 41.611 & 1.357618 & 2958.143 & 41.857 & 1.395233 \\
\hline 0.4 & 2.22391 & 3003.876 & 61.124 & 1.994258 & 2938.525 & 61.475 & 2.049167 \\
\hline 0.5 & 2.24203 & 2984.585 & 80.415 & 2.623654 & 2919.137 & 80.863 & 2.695433 \\
\hline
\end{tabular}

Source: Model simulations.

We conclude this section with an application in development economics. In the context of our simple $2 \times 2$ structure, a "stylized" account of a developing economy is one that is small, with a high tariff protecting a capital-intensive import-competing sector. The elasticity of factor substitution between capital and labor is likely to be higher in the import-competing sector than 
in the export sector. Table 5 reproduces this scenario with labor's share in the tariff protected X sector as 0.4 versus 0.8 in the $\mathrm{Y}$ sector. The factor substitution elasticity is assumed to be 0.8 in the $\mathrm{X}$ sector and 0.2 in the $\mathrm{Y}$ sector. Now, the policy objective in many developing countries is to bolster capital relative to growth in the labor force. So, we assume the policy is successful and that the capital supply grows at 3 percent while the labor supply grows at 1 percent.

As the first two columns of Table 5 show, any positive initial tariff has the effect of reducing the real growth rate in the presence of the posited pattern of factor accumulation. This suggests that as the country achieves its objective of continuing growth of capital per worker, the tariff is in part frustrating real growth. Or, the same thing, the proportional deadweight production cost of the tariff is itself growing due to the factor accumulation. The prudent policy maker would have one more reason to move to a lower tariff regime.

Table 5. The Tariff-Distorted Growth Rate is Less Than the No-Distortion Growth Rate

Initial values: $\theta_{\mathrm{LX}}=0.4, \theta_{\mathrm{LY}}=0.8$, tariff $=0, \sigma_{\mathrm{x}}=0.8, \sigma_{\mathrm{y}}=0.2$

$$
\text { With Factor Accumulation ( } \hat{K}=3, \hat{L}=1) \quad \text { Without Factor Accumulation }
$$

\begin{tabular}{ccccccccc}
$\begin{array}{c}\text { Tariff } \\
\text { Rate }\end{array}$ & $\begin{array}{c}\text { Growth } \\
\text { Rate }\end{array}$ & $\begin{array}{c}\text { Value of } \\
\text { Production } \\
\text { (At world } \\
\text { prices) }\end{array}$ & $\begin{array}{c}\text { Production } \\
\text { Cost } \\
\text { (In dollars) }\end{array}$ & $\begin{array}{c}\text { Production } \\
\text { Cost as a } \\
\text { of National } \\
\text { Income }\end{array}$ & $\begin{array}{c}\text { Value of } \\
\text { Production } \\
\text { (At world } \\
\text { prices) }\end{array}$ & $\begin{array}{c}\text { Production } \\
\text { Cost } \\
\text { (In dollars) }\end{array}$ & $\begin{array}{c}\text { Production } \\
\text { Cost as a \% of } \\
\text { National } \\
\text { Income }\end{array}$ \\
\hline & & & & & & & & \\
0.0 & 1.6667 & 3050.00 & 0.0 & 0.0 & 3000.00 & 0.0 & 0.0 \\
0.1 & 1.6607 & 3041.089 & 8.911 & 0.292164 & 2991.409 & 8.591 & 0.286367 \\
0.2 & 1.6407 & 3011.177 & 38.823 & 1.272885 & 2962.57 & 37.43 & 1.247667 \\
0.3 & 1.6009 & 2953.123 & 96.877 & 3.176295 & 2906.59 & 93.41 & 3.113667 \\
0.4 & 1.5298 & 2854.349 & 195.651 & 6.414787 & 2811.34 & 188.66 & 6.288667 \\
0.5 & 1.4008 & 2690.701 & 359.299 & 11.78029 & 2653.53 & 346.47 & 11.549
\end{tabular}

Source: Model simulations.

\section{Costs of Distortions and Growth: Some Estimates for Egypt}

In this section we use an applied general equilibrium model of the Egyptian economy to illustrate some of the interactions between policy distortions and factor growth. While other countries might also serve as useful examples, Egypt has in the past experienced some growth patterns amenable to illustrating our points. Also, Egyptian data, in the form of a social accounting matrix, is readily available. The model, which is described in detail in the Appendix, consists of six sectors (oil, service exports, manufactured exports, agriculture, imported 
manufactures, and a nontraded good) and eight factors of production (mobile labor and capital, and a specific factor in each sector). We retain the assumption of full employment, which is common in trade models, but obviously would not capture the situation in Egypt. Nevertheless, our results could be interpreted as being valid for a given level of aggregate employment. We assume that Egypt is unable to influence its terms of trade, so the price of the nontraded good adjusts to achieve an equilibrium. A representative household receives all factor income and net revenue collected from taxation. The model is benchmarked using data from a social accounting matrix for 1998, discussed in Löfgren and El-Said (1999).

Using 1998 data, Egypt is taken to have a tariff of 6.5 percent on agricultural goods and a 27.2 percent tariff on manufactured goods. Additionally, we model an excise tax on the nontraded good of 5 percent. The pattern of factor accumulation has varied in Egypt over time, but fits into two periods since 1977, according to Kheir-El-Din and Moursi (2002). Most recently, during the period of 1990 to 1998, the aggregate supply of labor to the Egyptian economy grew at the average annual rate of 2.61 percent, while the capital stock grew only 0.19 percent per year. Roughly a decade earlier, 1977 to 1989, aggregate labor supply grew at 2.41 percent a year, but the rate of capital accumulation was much faster: 7.25 percent. In our simulations reported below, we consider both factor growth scenarios.

Of course, in moving toward a more realistic application to illustrate our basic points, we necessarily depart from the simpler theoretical structure explored at length above. While the essential elements of that structure are still at work, clearly things do not accord strictly with equation (5) since now there are more sectors, specific factors, and a nontraded good. Also, with a nontraded good, the proportional change in real income, even when preferences are homothetic, no longer coincides with the proportional change in output evaluated at world prices. This is because the price of nontraded goods is endogenous and itself changing with growth. Nonetheless, the CGE structure has embedded in it the representative agent's preference structure - in this model, Cobb-Douglas - and so we are able to report on changes in real income using the utility function.

\section{The Period 1990 - 1998}

The upper portion of Table 6 reports the effects of eliminating the tariffs on agricultural and manufacturing goods, as well as the excise tax on the nontraded good, as they existed in 1998, for the pattern of factor accumulation that took place between 1990 and 1998. In Table 6, all the equivalent variation (EV) calculations are computed relative to the initial, tariff/tax distorted equilibrium without factor accumulation, with the except of column four as explained below. Columns two through five report the effects of factor accumulation at rates in the period 1990 to 1998 on Egypt's real growth rate, EV, the portion of EV that can be attributed to tariff and tax reform alone, and the total utility level for two different sets of tariff and tax rates: the 1998 rates (row 2) and a hypothetical scenario in which all distortions are removed (row 1). The last two columns of the table show the EV of moving to non-distorted prices and the total utility levels in the absence of any factor accumulation. 

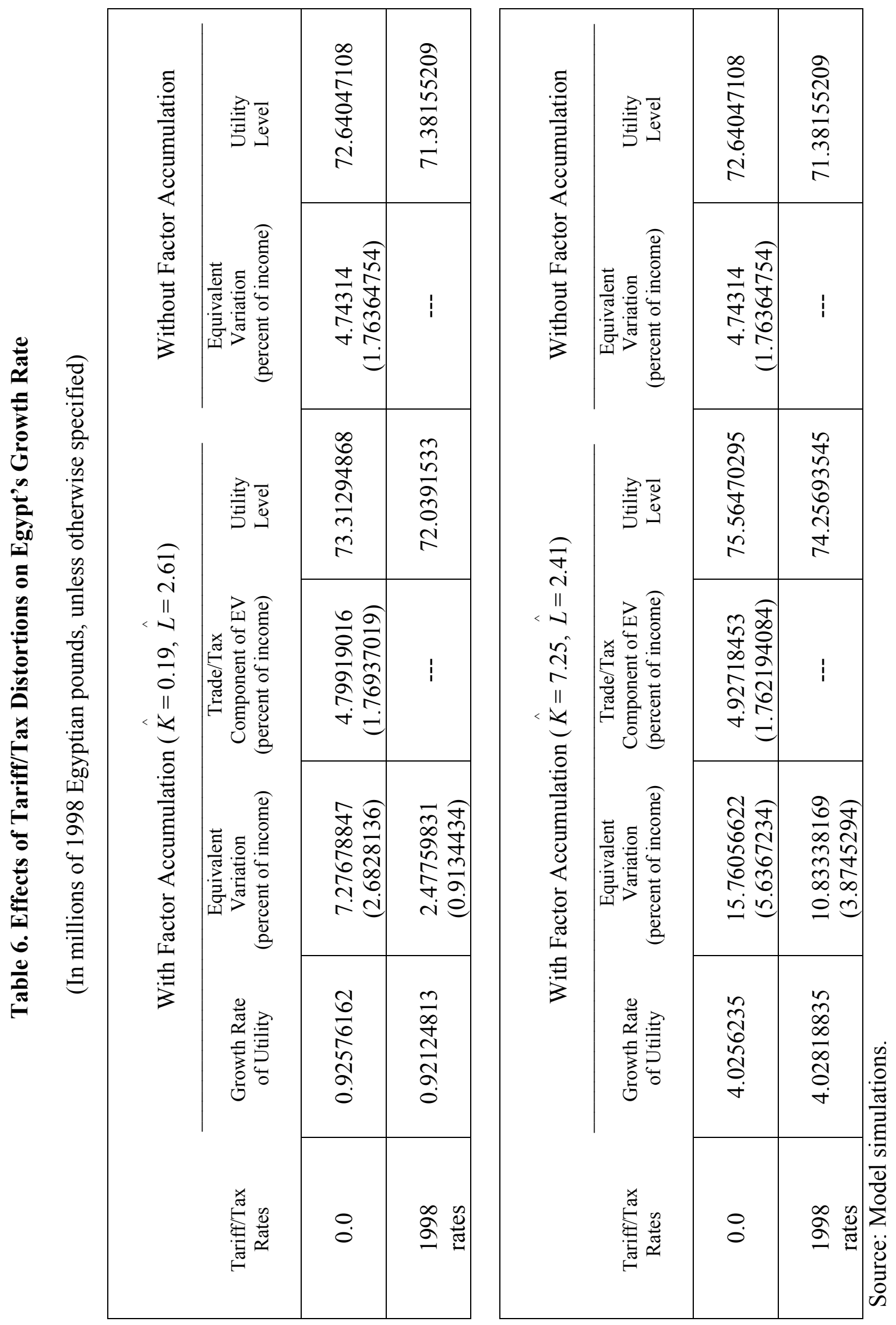
As reported in the upper section of Table 6, factor growth in Egypt in the presence of the 1998 tariff/tax mix would have led to a real growth rate of about 0.921 percent. In order to achieve the corresponding higher level of utility that results from the factor growth would require an equivalent variation in income of LE 2.477 million, or about 0.91 percent of national income annually, in the absence of factor accumulation. While the growth rate is not very high, owing largely to the low rate of capital accumulation during this period, it is nonetheless worth noting that the removal of all three policy distortions we consider would have resulted in an EV of LE 4.743 million, or 1.763 percent of national income, in the absence of factor growth. That is, the gain from removing distortions without any factor accumulation would be about twice the gain that accrues due to the factor growth but without altering any tariffs or taxes. Of course, we recognize that it is not realistic for Egypt to remove these three sources of government revenue simultaneously. But this calculation does serve to highlight just what the costs of the 1998 fiscal structure would have been. And, as governments pursue policies aimed to spur investment for growth, we are reminded that sometimes, as here, bigger gains are at hand through straight-forward trade and tax reforms even in the absence of factor accumulation.

Furthermore, column three of the upper portion of Table 6 reports an EV of LE 7.276 million resulting from the posited factor accumulation combined with the removal of all tariffs and taxes. This represents about 2.68 percent of national income annually. The fourth column isolates the component of this total EV attributable to the removal of trade tariff/tax distortions alone. (Mathematically, since the base prices are the same for each EV calculation, note that this is just the difference between the two entries in column three.) In particular, of the total LE 7.276 million gain to the Egyptian economy from growth and tax reduction, measured by the equivalent variation, LE 4.799 million of this owes to removal of the tariffs/taxes in the post-growth, larger economy. This represents 1.769 percent of national income. Compared with the relatively smaller gain from removing taxes in the absence of factor accumulation, 1.763 percent of national income, this suggests that the relative cost of the fiscal structure is growing for the given pattern of factor accumulation. Consistent with our earlier discussion of growth and distortions, note that the real growth rate, given the factor accumulation posited, rises with the elimination of the taxes from 0.9212 to 0.9258 percent in column two. This comparison deserves emphasis and highlights well our basic insight. The tariffs and the excise tax imposed a deadweight cost on the Egyptian economy equivalent to over one and three quarters percent of national income per year in 1998. And, in the presence of the most recent pattern of factor growth, this cost would have likely risen. In other words, the 1998 tariff/tax scheme considered in our model imposed a cost on the Egyptian economy and the most recent pattern of factor accumulation would have raised this cost

The Period 1977 - 1989

In this section, we repeat the above analysis but assume that Egypt would have been able to attain rates of factor accumulation identical to those achieved during the period from 1977 to 1989 . This scenario is of substantial interest to any country that aspires to achieve at least this rate of capital accumulation, if not higher. Therefore, a key policy question is how 
such a more rapid rate of capital accumulation would interact with the 1998 tariff $/ \operatorname{tax}$ scheme. The results are reported in the lower half of Table 6.

In this case, as shown in Table 6, the 1998 pattern of tariffs and the excise tax imposed a cost in the absence of factor accumulation of LE 4.743 million, or 1.763 percent of national income per year. With factor accumulation at the rates that occurred between 1977 and 1989, but given the 1998 tariff and tax rates, the gain to the economy would be equivalent to LE 10.833 million, or 3.874 percent of national income. If tariffs and the excise tax were eliminated, these same rates of factor accumulation would have led to higher real income as measured by the larger EV of LE 15.760 as shown in column three, or as shown in column five for utility levels, but a lower rate of growth: from 4.028 percent to 4.025 percent.

Unlike the previous case, if Egypt would have been able to attain rates of factor accumulation that matched those of the period between 1977 and 1989, then the cost of their 1998 tariff/tax structure would have fallen. This is confirmed in column four where once again the component of the overall EV attributable only to the elimination of trade and other taxes is isolated. That amount of LE 4.927 million represents 1.762 percent of national income compared with the relatively larger 1.763 percent resulting from tariff/tax elimination but without growth. This suggests that the cost of the fiscal structure is falling with factor accumulation. Thus, consistent with the earlier analysis, real growth is actually enhanced by the positive tariffs and taxes, increasing from 4.025 percent to 4.028 percent. The reason for this reversal in the pattern of Egypt's growth rate and overall cost of the 1998 tariff/tax scheme is due to the much faster rate of capital accumulation that took place between 1977 and 1989, since labor supply growth is about the same in both periods and nothing else changed. This would be expected from application of equation (5): the term $(K-L)$ switches sign for the period 1977 to 1989 , compared to the recent period of 1990 to 1998 , although, as noted above, the current model is not exactly that of equation (5).

In order to see the sectoral impacts of the two different patterns of factor accumulation, the relationship between Egypt's growth rate and the tariff or tax rate in each sector is plotted in Figure 3. The upper panel of Figure 3 (panel A) shows the relationship between Egypt's growth rate and the tariff rate on manufactured goods, for both patterns of factor accumulation. As shown, the relationship between Egypt's growth rate and the tariff on manufacturing goods is negative for the most recent pattern of factor accumulation, but positive for the pattern of factor accumulation between 1977-1989. This reversal is consistent with the prediction of equation (5), although the effects are substantially more complex because of the presence of a nontraded good and a specific factor in each sector. 
Figure 3. Relationship Between Egypt's Growth Rate and Distortions

Panel A. Relationship Between Egypt's Growth Rate and the Tariff Rate on Manufactured Goods

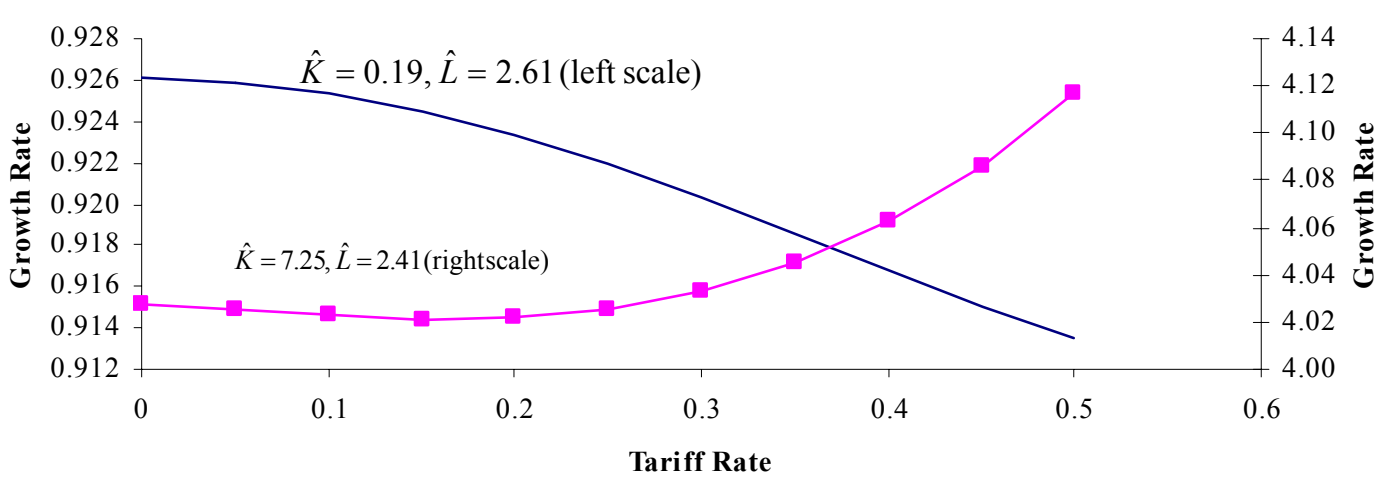

Panel B. Relationship Between Egypt's Growth Rate and the Tariff on Agricultural Goods

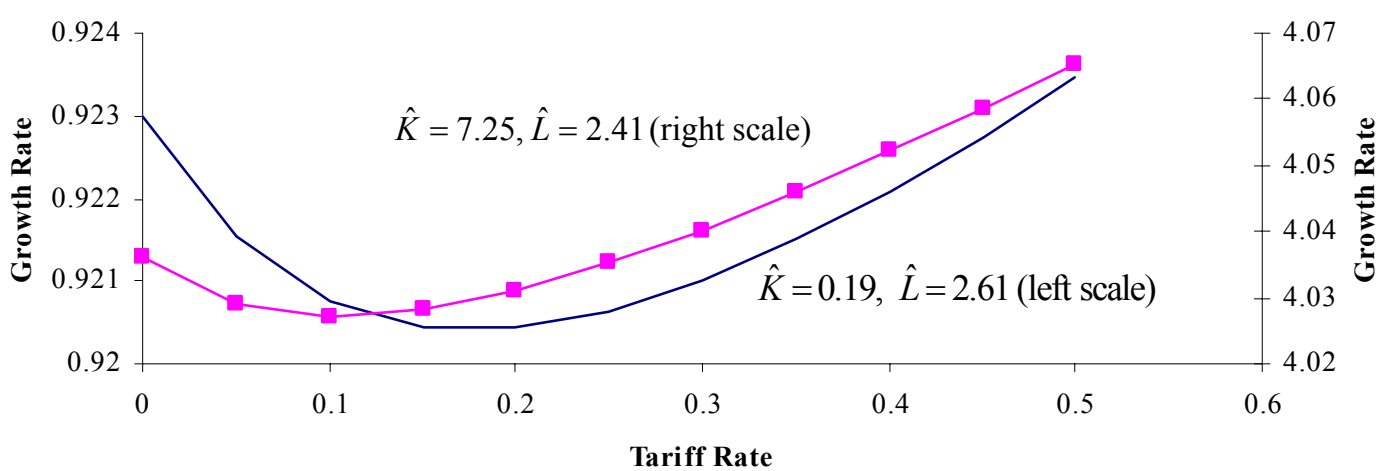

Panel C. Relationship Between Egypt's Growth Rate and the Excise Tax on Nontraded Goods

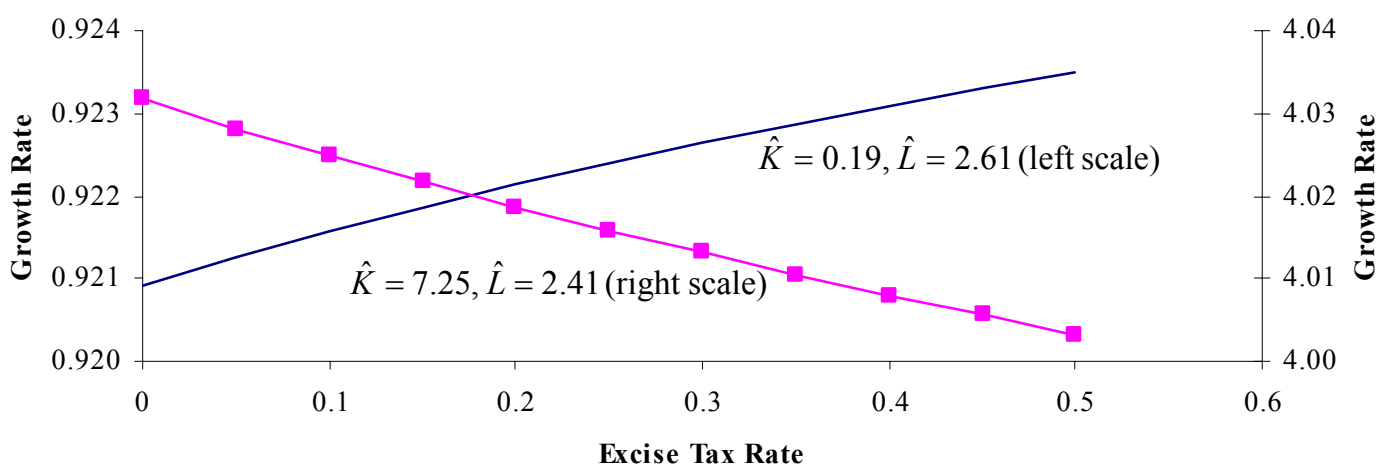


Panel B of figure 3 depicts the relationship between Egypt's growth rate and the tariff on agricultural goods. As shown, the relationship between the two exhibits a similar pattern, regardless of whether labor or capital grows more rapidly. Egypt's growth rate would have risen as a result of an increase in the tariff on agricultural goods in excess of about 10 percent for the earlier period of factor accumulation and in excess of about 20 percent for the most recent period of accumulation. This result largely comes about because increases in the agricultural tariff above 10 percent and 20 percent for the two respective periods offset the reduction in output that occurs as a result of the existing high tariff on manufactured goods. Consequently, for either pattern of factor accumulation, the cost of increases in the agricultural tariff rate above 10 or 20 percent would have declined, as a proportion of national income, which is consistent with a rising growth rate. Another factor working to reduce the cost of a higher tariff on agricultural goods is the presence of the nontraded sector. Output of the nontraded good rises as the tariff on agricultural goods increases, drawing resources away from other sectors. Output of the agricultural sector rises with a higher tariff, but it would have risen by even more in the absence of a nontraded good. This effect serves to reduce the cost of a higher agricultural tariff and thus contributes to a higher growth rate. Also, we found that raising the tariff rate on agricultural goods without any factor accumulation would have increased welfare within the range of 6.5 to 38 percent because rates in this range offset the effect of the high tariff on manufacturing goods.

Finally, panel $\mathrm{C}$ of Figure 3 shows that the cost of a higher tax on nontraded goods would have risen with the earlier pattern of factor accumulation, but would have fallen in the latest period. This is consistent with a decline in Egypt's growth rate in the earlier period and a higher growth in the latter period. Since the higher growth rate of capital in the earlier period is the main difference, and since the excise tax on nontraded goods is ad valorem, a possible explanation for the different patterns is that the higher income growth in the earlier period pushes up the price of nontraded goods and magnifies the distortionary cost of the excise tax.

As depicted in Figure 3, the relationship between Egypt's growth rate and the tariff rate on manufactured goods and the excise tax on the nontraded good would have been reversed for the two different configurations of factor accumulation. However, the relationship between Egypt's growth rate and the tariff on agricultural goods would have remained unaltered, despite two vastly different patterns of factor accumulation. This result, while strictly inconsistent with the prediction of equation (5), undoubtedly occurs because of complex interactions between changes in the agricultural tariff and the distortions in other sectors, realistic features of the Egypt model which go beyond the simpler structure that generates equation (5).

We explored alternative versions of the model in an attempt to identify which features were responsible for producing various results. For example, in a stripped-down version of the model in which the nontraded good was dropped, and only one distortion was retained (the agricultural tariff), Egypt's growth rate would have risen when the tariff rate on agricultural goods increased, for the two different patterns of factor accumulation discussed above. These results can be attributed to the expanded dimensionality of the model beyond 
the $2 \times 2$ structure, as well as the presence of sector-specific factors of production, since these are the only two ways in which the stripped-down version of the model differs from the $2 \times 2$ structure.

It is easy to see how the assumption of sector-specific factors might affect the relationship between $\mathrm{dg} / \mathrm{dt}$ and the tariff rate on agricultural goods, compared to the $2 \times 2$ model. In the $2 \times 2$ model, factor prices will be affected by changes in a tariff rate, in line with the Stolper-Samuelson predictions, but not by changes in factor endowments. If, for example, a tariff raises the wage-rent ratio, both sectors will want to become more capital intensive. This relationship will affect how the cost of a distortion might change in the presence of factor accumulation. In a specific-factors model, as we have in the CGE, changes in factor endowments will now alter factor prices, unlike in the $2 \times 2$ model. And, the changes in the wage-rent ratio that result from factor accumulation can be of opposite sign, depending on the pattern of factor accumulation. In the $2 \times 2$ model, the wage-rent ratio will move in only one direction, regardless of the pattern of factor accumulation, since it depends only on relative commodity prices, provided of course that there are no factor-intensity reversals.

\section{Conclusions and Implications For Structural Policy Reforms}

Real growth rates are dependent on the level of policy distortions regardless of their effect on the rate of factor accumulation. So, for example, a higher tariff regime could bring higher real growth rates even while lowering real income and without having any effect on factor accumulation. Of course, most policies are likely to also change the rate of factor accumulation in an economy through altered savings, labor market participation, and so on, which we well recognize. Nonetheless, while these latter channels between growth and distortions may be important, we have shown that, at least for the intermediate run, possibly decades, the simple presence of policy distortions may exert a large impact on real measured growth. Just which way the effects go, however, depends on the factor intensities, factor substitution elasticities in production, and the bias of factor accumulation.

We explored some possibilities by using four numerical simulation examples based on our theoretical section. With reasonable parameter values, we illustrated how for exogenously given rates of factor accumulation, an economy's real growth rate could be substantially higher with a 50 percent ad valorem import duty, compared to a zero tariff. Retaining the same parameter values, but reversing the bias of the factor accumulation would reverse the effect: a 50 percent tariff would result in a substantial reduction in the real growth rate compared with no tariff. Subsequent simulations explored some other possibilities with alternative factor intensities and factor substitution elasticities. Alternative patterns of tariff protection and growth rates emerged.

An important implication of our analysis is that any attempt to link tariff levels with growth rates empirically across countries needs to control for some structural parameters of each economy, including factor intensities, substitution elasticities in production, and the particular factor bias of growth over the period studied. Neglecting such variables could 
explain the poor econometric performance of regressions of growth on measures of tariff levels or openness.

Another important implication of our results is that the deadweight production costs of policy distortions change in the presence of factor accumulation, but in predictable ways. Thus, our approach should be useful to policymakers seeking to identify which distortions are likely to become more costly in a growing economy. In particular, using a multisector CGE model, we investigated the experience of Egypt over two decades of factor accumulation. We found that for the period 1990 to 1998, Egypt's 1998 tax and tariff structure would have become more costly in welfare terms on account of factor accumulation biased toward labor. For the period from 1977 to 1989, however, the welfare cost of the Egyptian tax and tariff mix, as existed in 1998, would have fallen on account of factor accumulation biased toward capital. More specifically, we identified which components of Egypt's tax structure would have contributed to this outcome. 


\section{References}

Baldwin, Richard, and Frederica Sbergami, (2000), "Non-Linearity In Openness and Growth Links: Theory and Evidence," Geneva: Graduate Institute of International Studies.

Baldwin, Robert, (2003), “Openness and Growth: What's the Empirical Relationship?" National Bureau of Economic Research, Working Paper 9578.

Berg, Andrew, and Anne Krueger, (2003), "Trade, Growth, and Poverty: A Selective Survey," International Monetary Fund, Working Paper 03/30.

Bhagwati, Jagdish, (1968), "Distortions and Immiserizing Growth: A Generalization," Review of Economic Studies, vol. 35, pp. 481-85.

Brander, James, and Paul Krugman, (1983), “A 'Reciprocal Dumping’ Model of International Trade,” Journal of International Economics, vol. 15, pp. 313-323.

Brecher, Richard, and Carlos Diaz-Alejandro, (1977), "Tariffs, Foreign Capital, and Immiserizing Growth,” Journal of International Economics, vol. 7, pp. 277-88.

Cassing, James, (1983), "A Note on Growth in the Presence of Tariffs," Journal of International Economics, vol. 14, pp. 115-121.

Clemens, Michael A. and Jefferey G. Williamson, (2001), “A Tariff-Growth Paradox? Protection's Impact the World Around 1875-1997," National Bureau of Economic Research, Working Paper 8459.

, (2002), "Why Did the Tariff-Growth Correlation Reverse After 1950?," National Bureau of Economic Research, Working Paper 9181.

Corden, W. Max, (1997), Trade Policy and Economic Welfare, Oxford University Press.

DeJong, David, and Marla Ripoll, (2003), "Tariffs and Growth: Comparing Relationships Among the Rich and Poor," University of Pittsburgh, manuscript.

Dimaranan, Betina V. and Robert A. McDougall, (2002), Global Trade, Assistance, and Production: The GTAP5 Data Base, Center for Global Trade Analysis, Purdue University.

Easterly, William, (1989), "Policy Distortions, Size of Government, and Growth" Policy Research Paper 344, Washington: The World Bank. , (1993), “How Much Do Distortions Affect Growth?” Policy Research Paper 1215, Washington: The World Bank. 
Edwards, Sebastian, (1998), “Openness, Productivity, and Growth: What Do We Really Know?”, Economic Journal, vol. 108, pp. 383-398.

Grossman, Gene M. and Elhanan Helpman, (1991), Innovation and Growth in the Global Economy, Cambridge, MA: The MIT Press.

Harrison, Anne, (1996), "Openness and Growth: A Time Series, Cross-Country Analysis For Developing Countries, Journal of Development Economics, vol. 48, pp. 419-447.

Harrison, Anne, and Gordon Hanson, (1999), "Who Gains From Trade Reform? Some Remaining Puzzles," Journal of Development Economics, vol. 59, pp. 125-154.

Johnson, Harry, (1967), “The Possibility of Income Losses From Increased Efficiency or Factor Accumulation in the Presence of Tariffs," Economic Journal, vol. 77, pp. 151-54. , (1970), "A Note on Distortions and the Rate of Growth of an Open Economy," Economic Journal, vol. 80, pp. 990-92.

Jones, Ronald W., (1965), “The Structure of Simple General Equilibrium Models," Journal of Political Economy, vol. 73, pp. 557-572.

Jones, Ronald W., and José Scheinkman, (1977), "The Relevance of the Two-Sector Production Model in Trade Theory," Journal of Political Economy, vol. 85, no. 5, pp. 909936.

Kheir El-Din, and Tarek Moursi, (2002), "Sources of Economic Growth and Technical Progress in Egypt: An Aggregate Perspective," Cairo University.

Krueger, Anne, (1978), Foreign Trade Regimes and Economic Development: Liberalization Attempts and Consequences, Cambridge: Ballinger Press.

Levine, Ross, and D. Renelt, (1992), “A Sensitivity Analysis of Cross-Country Growth Regressions," American Economic Review, vol. 84, no. 4, pp. 942-963.

Löfgren, Hans, and Motaz El-Said, (1999), "A General Equilibrium Analysis of Alternative Scenarios For Food Subsidy Reform in Egypt," Washington: International Food Policy Research Institute, Discussion Paper no. 48.

Mansur, Ahsan, and John Whalley, (1984), "Numerical Specification of Applied General Equilibrium Models: Estimation, Calibration, and Data," in Applied General Equilibrium Analysis, edited by Herbert Scarf and John Shoven, Cambridge: Cambridge University Press, pp. 69-127.

Parente, Stephen, and Edward Prescott, (2002), Barriers to Riches, Cambridge: MIT Press. 
Rivera-Batiz, Luis, and Paul Romer, (1991), "International Trade With Endogenous Technological Change,” European Economic Review, vol. 35, pp. 971-1004.

Rodriquez, Francisco, and Dani Rodrik, (2001), "Trade Policy and Economic Growth: A Skeptic's Guide to the Cross-National Evidence, NBER Macroeconomics Annual 2000, edited by Ben Bernanke and Kenneth Rogoff, Cambridge.

Sachs, Jeffrey, and Andrew Warner, (1995), "Economic Reform and The Process of Global Integration," Brookings Papers on Economic Activity, no. 1, pp. 1-118.

Sala-i-Martin, Xavier, (1997), "I Just Ran Two Million Regressions," American Economic Review, vol. 82, pp. 178-83.

Wacziarg, Romain, and Karen Horn Welch, (2003), “Trade Liberalization and Growth: New Evidence," National Bureau of Economic Research, Working Paper 10152.

Young, Alwyn, (1995), "The Tyranny of Numbers: Confronting the Statistical Realities of the East Asian Growth Experience," Quarterly Journal of Economics, vol. 110, pp. 643-80. 


\section{Appendix: Structure of the Applied General Equilibrium Model}

\section{Model Structure}

This paper uses an applied general equilibrium model of the Egyptian economy that consists of six sectors (oil, service exports, manufactured exports, agriculture, imported manufactures, and a nontraded good) and eight factors of production (labor, capital, and a sector-specific factor). Labor and capital are mobile across all sectors. A representative household receives all factor income, as well as all revenue collected from taxation. Egypt is assumed to be a small country, so the terms of trade are exogenous. The price of nontraded goods adjusts to bring about equilibrium in the goods market.

\section{Production Structure}

Value added in each sector $\mathrm{VA}_{\mathrm{j}}$ is produced by combining a labor input $\mathrm{L}_{\mathrm{j}}$, with capital $\mathrm{K}_{\mathrm{j}}$ and a specific factor $\mathrm{F}_{\mathrm{j}}$ according to a constant elasticity of substitution (CES) production function:

$$
X_{j}=A_{j}\left[\alpha_{j} L_{j}^{-\rho_{j}}+\beta_{j} K_{j}^{-\rho_{j}}+\left(1-\alpha_{j}-\beta_{j}\right) F_{j}^{-\rho_{j}}\right]^{\left(-1 / \rho_{j}\right)}
$$

where $\mathrm{A}_{\mathrm{j}}, \alpha_{\mathrm{j}}$, and $\beta_{\mathrm{j}}$, are constants, and $\rho_{j}=\frac{\left(1-\sigma_{j}\right)}{\sigma_{j}}$ where $\sigma_{\mathrm{j}}$ is the elasticity of substitution between factors in sector $\mathrm{j}$. Note that this specification assumes that the elasticity of substitution among all three factors is the same within a given sector. The allocation of the mobile factors - labor and capital - across sectors is determined by equating the value of the marginal product of each factor with its factor price. For labor, this is where the value of the marginal product of labor equals the aggregate wage rate:

$$
W=\frac{\partial X_{j}}{\partial L_{j}} P D_{j}
$$

where $\mathrm{PD}_{\mathrm{j}}$ is the consumption price of the $\mathrm{jth}$ good and $\mathrm{W}$ is the wage rate. Similarly for capital:

$$
R=\frac{\partial X_{j}}{\partial K_{j}} P D_{j}
$$

where $\mathrm{R}$ is the rental rate on capital. Each factor must be fully employed, so

$\sum_{j} L_{j}=\bar{L}$

and 
$\sum_{j} K_{j}=\bar{K}$

The return to the specific factor in each sector, $\mathrm{f}_{\mathrm{j}}$, is determined as a residual (since $\mathrm{F}_{\mathrm{j}}$ is fixed) so as to satisfy a zero-profit condition:

$P S_{j} V A_{j}=W L_{j}+R K_{j}+f_{j} F_{j}$

where $\mathrm{PS}_{\mathrm{j}}$ is the producer price of good $\mathrm{j}$.

Aggregate income and demand

Aggregate income available for spending by the representative consumer (Y) equals the sum of factor income, government revenue, and foreign borrowing, B, which is assumed to be fixed in terms of the numeraire:

$Y=W \bar{L}+R \bar{K}+\sum_{j} f_{j} F_{j}+G R+B$

Government revenue equals indirect tax revenue plus tariff revenue:

$$
G R=\sum_{j} t x_{j} P S_{j} X_{j}+\sum_{j} t m_{j} P W_{j} M D_{j}
$$

where $\mathrm{tx}_{\mathrm{j}}$ is the indirect tax (or subsidy rate if negative) on good $\mathrm{j}, \mathrm{tm}_{\mathrm{j}}$ is the tariff rate on good $\mathrm{j}, \mathrm{PW}_{\mathrm{j}}$ is the international price of good $\mathrm{j}$, and $\mathrm{MD}_{\mathrm{j}}$ are imports of good $\mathrm{j}$. As imports are treated as perfect substitutes for domestically produced goods, imports equal the difference between domestic demand and production.

Aggregate demand

Absent information on elasticities of demand in Egypt, we assume that a representative consumer maximizes a Cobb-Douglass utility function defined over the six goods. The resulting demand functions are:

$D D_{j}=\frac{s_{j} Y}{P D_{j}}$ 
where $P D_{j}$ is the consumer price (inclusive of taxes or tariffs), $D D_{j}$ is the demand for good $\mathrm{j}$, and $s_{j}$ is the budget share of good $\mathrm{j}$. Of course, with this demand structure, the own-price elasticity of demand is -1 , the cross-price elasticities are zero, and the income elasticity of demand is 1 .

The prices paid by the consumer differ from the prices received by the producer, due to indirect taxes. Furthermore, for the traded goods, prices paid by the consumer and received by the producer differ from world prices as a result of tariffs on imports. For imported goods:

$$
P S_{j}=P W_{j}\left(1+t m_{j}\right)
$$

while for exported goods, the producer price equals the world price, since there are no export taxes or subsidies:

$$
P S_{j}=P W_{j}
$$

For commodities subject to a consumption tax, the price paid by the consumer differs from the price received by the producer according to:

$$
P D_{j}=P S_{j}\left(1+t x_{j}\right)
$$

\section{Equilibrium}

Equilibrium in the model is achieved when a set of factor prices is found that generates zero profits in each sector and is consistent with full employment of each factor. In this model, the terms of trade are given exogenously, so the price of the nontraded good adjusts to achieve equilibrium. In the nontraded sector, demand must equal supply:

$D D_{N}=X_{N}$

For the imported good:

$$
D D_{M}=X_{M}+M D_{M}
$$

while for the exported good:

$$
D D_{X}+E_{X}=X_{X}
$$

where $E_{j}$ are exports of good $j$. 


\section{Data, Elasticities, and Parameter Values}

The simulation results in Tables 2 through 5 were generated using hypothetical values for factor intensities and the substitution elasticities. Parameter values are determined by the technique of calibration, described in Mansur and Whalley (1984). Calibration entails using data on exogenous and endogenous variables in the base year to "solve for" unknown parameter values. Because of this technique, the model will replicate the base year data exactly, that is, the model will produce values for all the endogenous variables that match the observed values.

The results from the simulations in Table 6 and Figure 3 are based on data for the Egyptian economy for 1998, taken from a social accounting matrix compiled by Löfgren and El-Said (1999). Parameter values are determined by the technique of calibration (described above), and thus, the model replicates the structure of the Egyptian economy in 1998. The rates of growth in the capital stock and the labor force are taken from Kheir-El-Din and Moursi (2002). In production, values for the elasticity of substitution are taken from Dimaranan and McDougall (1997). The tariff rate on agricultural goods is taken to be 6.5 percent and 27.2 percent on manufacturing goods. We also model an excise tax of 5 percent on the nontraded good. 